\title{
REFORMASI GEREJA, JOHN CALVIN, DAN ISLAM
}

\author{
Markus Dominggus Lere Dawa
}

\begin{abstract}
Abstrak: Tulisan ini berupaya menginvestigasi peran yang dimainkan Islam pada terjadinya Reformasi Gereja abad ke-16, yang berlangsung di masa puncak kejayaan Kerajaan Islam Ottoman-Turki dan di tengah-tengah upaya kerajaan tersebut meluaskan daerah kekuasaannya ke Eropa. Pertemuan-pertemuan dengan Islam dalam cara-cara yang seperti ini melahirkan persepsipersepsi tersendiri terhadap Islam, yang pada tokoh-tokoh Reformator seperti Calvin dikaitkan dengan pandangan teologinya. Bahwa persepsi-persepsi itu umumnya negatif harus diterima sebagai suatu produk dari zaman yang tersendiri, dan tidak bisa ditransfer begitu saja ke masa kini yang sama sekali berbeda.
\end{abstract}

Kata-kata Kunci: Reformasi, Eropa Barat Kristen, Islam, John Calvin, persepsi.

Abstract: This article attempt to be investigating the role Islam played surrounding Reformation. As Reformation in the time when the Ottoman sultanate was at its peak and was invading Europe for the sake of expanding its territory, it tries to find the connection that possibly exist. On the other hand, it also intends to depict the negative percetions on Islam that were formed under circumstances like these among Europeans Christians, particularly among the Reformers such as Calvin. Those perceptions are products of its time. They should not be transferred into present situation, which is very different from the time of the Reformers.

Keywords: Reformation, Christian West European, Islam, John Calvin, perseption. 


\section{PENDAHULUAN}

Seperti ditegaskan oleh Emidio Campi, mantan profesor teologi di Universitas Zurich, pokok artikel ini masih belum banyak disentuh dalam studi-studi mengenai Reformasi Gereja abad ke-16. Hal ini berbeda, misalnya, dari pembahasan Reformasi secara umum, atau Reformasi Luther, atau topik-topik yang berhubungan dengan orang-orang Yahudi dan Yudaisme dalam Reformasi. ${ }^{1}$ Sepemahaman penulis, studi-studi yang tersedia dalam bahasa Indonesia pun boleh dikatakan tidak ada. Sebuah paragraf dalam buku Aritonang yang membahas lika-liku relasi Kristen dan Islam di Indonesia sempat menyebutkan tentang sikap negatif orangorang Belanda terhadap Islam dan umat Islam, yang dihubungkan dengan Reformasi Protestan abad ke-16. Sikap negatif tersebut dikatakan diwarisi dari masa Perang Salib dan pengaruh sikap negatif tokoh-tokoh Reformasi Gereja terhadap Islam. Walau demikian diakui bahwa sikap itu tidak sehebat dan sedalam bangsa Portugis dan Spanyol yang punya pengalaman langsung dan traumatis dengan penguasa dan umat Islam. ${ }^{2}$

Bahwa dari satu sisi studi semacam ini mungkin terlihat kecil atau mungkin tidak ada sama sekali relevansinya dengan kehidupan gereja di Indonesia, namun di sisi lain mungkin saja terjadi, tanpa betul-betul disadari, bahwa ia justru relevan sekali dengan kehidupan gereja-gereja di Indonesia mengingat teks-teks dari sejumlah tokoh Reformasi masih terus dibaca oleh orang-orang Kristen di Indonesia. Di dalam tulisan tokoh ini rujukan-rujukan tentang Islam dapat ditemukan dalam jumlah yang cukup banyak. Sejauh mana dan sedalam apa hal itu mempengaruhi cara berpikir orang Kristen Indonesia terhadap Islam, hal itu tentu perlu

\footnotetext{
${ }^{1}$ Emidio Campi, "Early Reformed Attitudes towards Islam", Theological Review 31, 2010: 131.

${ }^{2}$ Jan S. Aritonang, Sejarah Perjumpaan Kristen dan Islam di Indonesia (Jakarta: BPK Gunung Mulia, 2006), 46.
} 
penelitian lain. Bisa saja terjadi bahwa gambaran sebagian orang Kristen Indonesia tentang Islam dan orang muslim dipengaruhi oleh apa yang terbaca dalam teks-teks itu. Namun sekali lagi hal itu bukanlah fokus perhatian tulisan ini.

Apa yang mau disajikan di sini adalah semacam sketsa yang melukiskan Reformasi abad ke-16 dan tokoh-tokohnya dalam hubungannya dengan Islam. Hendak disajikan di sini pengaruhpengaruh yang dimainkan Islam terhadap Reformasi, yang selama ini dominan sebagai tindakan pembaharuan internal gereja sematamata. Faktor-faktor lain yang melingkupinya, seperti faktor-faktor sosiologis, politis, ekonomis, dan lain-lain cukup banyak dikesampingkan, kalau tidak mau dikatakan diabaikan sama sekali. Harapannya ialah supaya lukisan Reformasi Gereja abad ke-16 itu kemudian dapat dipahami lebih utuh lagi.

Tulisan ini akan dibagi dalam tiga bagian besar. Pertama akan diberi suatu uraian tentang dunia Eropa Barat yang mengitari Reformasi dalam kaitannya dengan Islam dan umat muslim serta di mana peran yang dimainkan oleh Islam pada kejadian dan kelangsungan Reformasi. Pembahasan kemudian dilanjutkan dengan mendiskusikan persepsi orang-orang Kristen Eropa Barat tentang Islam sebelum dan pada masa Reformasi. Bagian selanjutnya memberikan sebuah catatan khusus pada pikiran John Calvin tentang Islam. Tulisan ini kemudian diakhiri dengan sebuah simpulan.

\section{ISLAM DAN REFORMASI PROTESTAN}

Pada zaman sebelum dan cukup lama setelah Reformasi, orang-orang di Eropa tidak memakai istilah "Islam" atau "orang muslim" seperti orang pada zaman sekarang. Pada masa itu, istilahistilah yang dipakai untuk menyebut Islam dan orang muslim 
adalah orang-orang Turki (Turks), orang Saracens (Saracens), kaum Muhamadan (Mahomedans), dan kadang-kadang orang Ismail (Ismailites) atau bahkan disebut kafir (heathens). ${ }^{3}$ Meskipun secara etnis dan budaya orang-orang tersebut tidak sama namun karena kurangnya pengetahuan dan pemahaman maka orang-orang Eropa menyamakan saja semuanya. ${ }^{4}$

Orang Saracens, misalnya. Ini adalah istilah yang diambil dari bahasa Prancis kuno, Sarrazin, yang berasal dari kata Latin Saracenus. Kata ini berasal dari kata Yunani Sarakenos, yang diyakini berasal dari kata Arab sharq yang berarti timur atau matahari terbit. Ptolemius, penulis Yunani kuno, memakai kata itu untuk menyebut orang-orang Siria dan Irak. Di kemudian hari, orang-orang Romawi meski menaruk respek pada keahlian mereka dalam berperang namun menggolongkan mereka dalam kelas orang-orang barbar (barbarians). Walau demikian, orang-orang Romawi membedakan orang-orang Saracens ini dari orang-orang Arab. $^{5}$

Pada masa sebelum, menjelang, pada saat, dan sesudah Reformasi, istilah umum yang cukup umum dipergunakan untuk menyebut Islam dan orang muslim adalah Turks (orang-orang Turki). Soykut mencatat bahwa di Italia pada masa itu ada ungkapan yang berbunyi il farsi Turco, yang berarti "menjadi seorang Turki." Istilah ini dipahami bermakna "to convert to Islam" - pindah agama menjadi Islam; dan dipergunakan untuk menyebut para rinnegati, orang-orang Kristen yang pindah agama menjadi

\footnotetext{
${ }^{3}$ Reformation and Islam: A Stimulus Paper from the Conference for Islam Issues of the Evangelical Church in Germany [EKD] (Hannover: Evangelische Kirche in Deutschland [EKD], 2016), 11.

${ }^{4}$ Mustafa Soykut, The Image of the Turk in Italy: A History of the "Other" in Early Modern Europe: 1453 -1683 (Berlin: Klaus Schwarz Verlag, 2001), 8.

${ }^{5}$ Kallie Szczepanski, "Who were the Saracens" dalam https://www.thoughtco.com/who-were-the-saracens-195413 (diakses pada 27 Juli 2017).
} 
Islam. ${ }^{6}$ Dalam tulisan-tulisan Luther maupun Calvin, istilah Turks adalah istilah standar yang dipakai untuk menyebut orang Islam dan agamanya.

\section{Apa Hubungan Reformasi Gereja pada Abad ke-16 dengan Islam?}

Reformasi Protestan yang diinisiasi Martin Luther pada tahun 1517 terjadi di abad di mana Kekaisaran Ottoman Turki sedang berada di puncak kekuasaannya. ${ }^{7}$ Sekalipun tidak disukai dan ditakuti oleh orang-orang Eropa, Kekaisaran Ottoman juga dihormati dan dikagumi. Mereka bahkan dibayangkan sebagai gambaran ideal dari bagaimana seharusnya sebuah kerajaan Kristen yang kuat. Orang-orang Turki juga dipuji karena keberaniannya dalam bertempur, ketaatannya pada penguasa, dalam soal disiplinnya, ketekunannya, keadilannya, ketertibannya, dan banyak hal lain yang orang lihat kurang pada orang-orang Kristen. ${ }^{8}$

Kekaisaran ini dibangun pada sekitar abad ke-14 oleh seorang panglima perang Turki bernama Osman (1258-1326) dari puing-puing peradaban Islam di Asia Tengah sampai Barat, yang hancur akibat invasi Kekaisaran Mongol pada abad XIII. Dari situ ia terus tumbuh menjadi kekuatan imperial yang besar dan ditakuti. Mewarisi semangat penyebarluasan wilayah agama, mereka memandang dirinya sebagai yang dipilih khusus untuk menjadi pedang Allah yang "blazing forth the way of Islam from the East to

\footnotetext{
${ }^{6}$ Soykut, The Image of the Turk in Italy, 8.

${ }^{7}$ Martha Frederiks, "Introduction: Christians, Muslims and Empires in the 16th Century," Christian-Muslim Relation: A Bibliographical History Volume 6. Western Europe (1500-1600), David Thomas \& John Chesworth, eds.(Leiden: Koninklijke Brill NV, 2014), 1.

${ }^{8}$ Soykut, The Image of the Turk in Italy, 8.
} 
the West." Tidak sampai satu abad sejak kemunculannya, Kekaisaran Ottoman (atau Turki Usmani) sudah mampu menyerang Eropa. Kota Konstantinopel (Istanbul), bekas ibukota kekaisaran Romawi Timur, berhasil direbut dan ditaklukkan. ${ }^{10}$ Tidak berhenti sampai di situ, mereka terus merangsek ke arah Eropa Timur dan Tengah, menaklukkan negara-negara Eropa yang ada di sekitar situ.

Empat tahun setelah Luther memakukan 95 butir protesnya di pintu gerbang gereja kota Wittenberg, di bawah pimpinan Sultan Suleyman, tentara Ottoman berhasil merebut kota Belgrade pada tahun 1521. ${ }^{11}$ Lima tahun kemudian, pada tahun 1926, giliran kota Mohács di Hongaria jatuh. Dan tidak lama setelah itu, pada tahun 1929, orang-orang Eropa Barat dengan cemas dan gelisah telah melihat tentara Ottoman berdiri di depan mereka, mengepung kota Vienna (Wina, Austria). ${ }^{12}$

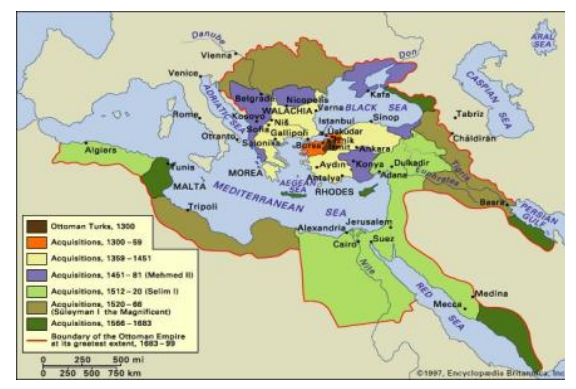

Daerah Kekuasaan Kekaisaran Ottoman

Sebelum Reformasi gereja dimulai, dunia politik Eropa turut dibuat hiruk pikuk dengan kabar kemajuan pasukan Ottoman

\footnotetext{
${ }^{9}$ Adam S. Fransisco, "Luther, Lutheranism and the Challenge of Islam," Concordia Theological Quaterly 71 (2007): 286. Terjemahan: "membuka jalan maju untuk Islam dari Timur ke Barat.'

${ }^{10}$ Fransisco, Concordia Theological Quaterly 71 (2007): 287.

${ }^{11}$ Reformation and Islam, 11.

${ }^{12}$ Ibid., 11.
} 
menuju Eropa. Dan tengah-tengah situasi invasi itulah Reformasi Protestan yang diinisiasi Martin Luther terjadi. Persoalan yang kemudian menggelitik nalar ialah adakah hubungan di antara invasi Kekaisaran Islam Ottoman dengan Reformasi Protestan?

Kalau hubungan yang dicari bersifat teologis mungkin jawabnya sukar ditemukan. Namun peneliti-peneliti sejarah abad pertengahan sampai modern awal pada masa kini sepakat bahwa Reformasi Protestan tidak bisa berjalan lancar dan sedemikian berhasil tanpa peran yang dimainkan oleh orang-orang muslim, dalam hal ini tentara Kekaisaran Ottoman, dalam konstelasi politik Eropa pada masa itu. Invasi kekaisaran Ottoman yang bermaksud menaklukkan seluruh Eropa di bawah kekuasaan Islam telah menciptakan suatu situasi sosial-politik yang memungkinkan Reformasi Protestan dapat berlangsung tanpa mendapat perlawanan yang semestinya. Situasi itu pertama-tama ialah ancaman militer Ottoman dan yang lain adalah bangkitnya negara-negara kota di Italia untuk memisahkan diri dari kekuasaan kepausan. Goffman mencatat bahwa sebenarnya Paus bersama dengan Holy Roman Emperor, Kaisar Charles V, telah bersumpah untuk memaksa Luther, Calvin dan orang-orang Protestan lainnya meninggalkan keyakinan mereka. Namun ikhtiar yang juga turut dibantu oleh raja Francis I dari Prancis itu tidak bisa dilaksanakan sepenuhnya karena di saat yang bersamaan mereka harus berjuang habishabisan melawan invasi Ottoman dan keadaan yang tengah berlangsung di Italia. ${ }^{13}$

\footnotetext{
${ }^{13}$ Daniel Goffman, The Ottoman Empire and Early Modern Europe (Cambridge, UK.: Cambridge University Press, 2004), 110. Dalam penelitian Martha Fredriks, upaya melawan Protestantisme juga tampak tidak bisa sepenuh tenaga karena Raja Francis I dan Kaisar Charles V tidak benar-benar sejalan. Raja Francis I tidak terlalu senang dengan Kaisar Charles V sebab kekuasaannya lebih besar dan mengurung wilayah kekuasaan Francis I. Pada tahun 1536 raja Francis I bahkan sempat beraliansi dengan Kekaisaran Ottoman untuk mengepung Kaisar Charles V. Lihat Frederiks dalam Christian-Muslim Relation: A Bibliographical History Volume 6, 5.
} 
Intinya, serangan Ottoman telah menciptakan suatu ruang yang subur bagi Luther dan gerakan Reformasi gereja serta para pendukungnya di Jerman, Swiss, dan lain-lain mendapat pijakan untuk bertahan, tumbuh, dan terus berkembang.

Meski tidak berpihak pada orang-orang Turki Ottoman, di masa-masa awal Reformasi, Luther tidak dapat menyembunyikan keyakinannya bahwa "God was using the Turks as a means to punish a doctrinally corrupt and morally lax Christendom"14 Allah sedang memakai orang-orang Turki untuk menghukum negara-negara Kristen yang korup dan bermoral rendah. Bahkan ketika ditanya kemungkinan untuk bangkit melakukan perang salib melawan orang-orang Turki Ottoman itu, Luther tidak sependapat. Baginya, ancaman sebenarnya bagi Eropa dan kekristenan saat itu bukanlah Turki Ottoman melainkan penyesatan ajaran gereja yang sedang dilakukan oleh kepausan. ${ }^{15}$ Namun sikap ini dikoreksi Luther beberapa tahun kemudian, setelah tentara Ottoman mencapai Kota Vienna. Pada masa inilah terbit tulisannya yang berjudul Against the Turk (1529). Dalam traktat ini, orang-orang Turki berubah menjadi "the servant of the devil, who not only devastates land and people with the sword... but lays waste the Christian faith and our dear Lord Jesus Christ" ${ }^{\text {"16 }}$ - alat setan untuk menghancurkan negeri, umat, dan iman Kristen. Karena itu pada masa ini pula ia menyusun Katekismus Kecil Luther ${ }^{17}$ sebagai suatu bahan pelajaran iman yang dapat dipergunakan oleh orang Kristen bila suatu saat nanti Eropa takluk di bawah Islam. Dari sejumlah informasi yang diketahuinya, Luther tampaknya cemas bahwa di bawah kekuasaan Islam akan membuat banyak orang

\footnotetext{
${ }^{14}$ Adam S. Fransisco, Martin Luther and Islam: A Study in Sixteenth-Century Polemics and Apologetics (Leiden: Koninklijke Brill NV, 2007), 67.

${ }^{15}$ Ibid., 67.

${ }^{16}$ Goffman, The Ottoman Empire and Early Modern Europe, 109.

${ }^{17}$ Lihat Reformation and Islam, 11.
} 
menjadi murtad bila mereka tidak mengerti isi imannya. ${ }^{18}$ Mulai saat ini dan selanjutnya dalam Reformasi Protestan, Islam dan orang-orang Muslim benar-benar dipersepsi sangat negatif.

\section{Islam dalam Persepsi Orang Kristen Eropa Barat sampai Era Reformasi Protestan}

Seperti dicatat Hugh Goddard, perjumpaan gereja-gereja Barat dengan Islam terjadi lebih belakangan setelah perjumpaan gereja-gereja Kristen di Timur. ${ }^{19}$ Namun perbedaan yang muncul di antara keduanya, apakah itu dalam soal bahasa (Yunani versus Latin), konteks intelektual yang berbeda, arah yang ditempuh dalam berteologi dan faktor-faktor lain yang menciptakan perbedaan-perbedaan, membuat yang satu tidak dapat belajar dengan baik dari yang lain. Perjumpaannya yang lebih awal dengan Islam telah membuat gereja-gereja di Timur telah memiliki, apa yang disebut Goddard "Christian interpretations of, and response to, Islam." 20 Namun hal itu menjadi tidak termanfaatkan dengan baik oleh saudara-saudarinya di Barat. ${ }^{21}$ Gereja-gereja di Barat, dapat dikatakan, akhirnya menyusun sendiri interpretasiinterpretasi dan respons-responsnya terhadap Islam, yang berangkat dari situasi kontekstualnya sendiri.

Perjumpaan orang-orang Eropa Barat dengan orang-orang dari Timur sudah terjadi jauh sebelum Islam lahir pada abad ke-7 di jazirah Arab. Perjumpaan ini menghasilkan sebuah persepsi tersendiri tentang "orang lain" (the other) dari Timur itu dan

${ }^{18}$ Fransisco, Concordia Theological Quaterly 71 (2007): 288.

${ }^{19}$ Hugh Goddard, A History of Christian-Muslim Relations (Edinburgh, UK.: Edinburgh University Press, 2000), 79. Di antara para apologis Gereja Timur yang sempat menyusun risalah-risalah tentang Islam adalah Yohanes dari Damaskus (676-749) dan Theodore Abu Qurrah (750-820). Lihat Fransisco, Concordia Theological Quaterly 71 (2007): 285.

${ }^{20}$ Fransisco, Concordia Theological Quaterly 71 (2007): 285.

${ }^{21}$ Ibid. 
sekaligus mempengaruhi persepsi orang Eropa Barat sendiri tentang "dirinya" (the self). Persepsi ini tidak pernah baku. Ia terus berubah menurut situasi dan kondisi sejarah yang juga terusmenerus berubah. ${ }^{22}$ Setelah Islam muncul dan seiring dengan makin meningkatnya frekuensi dan bentuk interaksi yang dimasuki dengan orang-orang Islam persepsi orang-orang Eropa Barat Kristen tentang Islam pun turut mengalami perubahan.

Perjumpaan signifikan orang-orang Eropa Barat dengan Islam dimulai pada penaklukan Spanyol pada awal abad ke-8. Penaklukan itu membuat seluruh Semenanjung Iberia berada di bawah kekuasaan Islam. ${ }^{23}$ Tidak berhenti sampai di situ saja, tentara-tentara Islam terus merangsek ke utara sampai pernah mencapai jarak sekitar dua ratus kilometer selatan Paris. ${ }^{24}$ Gerakan militer sejauh itu membawa Islam ke dalam kesadaran orang-orang Eropa Barat. Namun dari kejadian-kejadian yang terjadi di Spanyol inilah respons-respons orang-orang Eropa Barat terhadap Islam, menurut Goddard, dibentuk dan persepsi tentang Islam sebagai ancaman mulai diformulasikan. ${ }^{25}$

Orang-orang Eropa Kristen Barat yang hidup sebagai taklukan Kekalifahan Umayyah di Kordoba, Spanyol, adalah warga negara kelas dua berstatus dhimmi, yang dilindungi dan ditoleransi agamanya. Mereka boleh beribadah dengan bebas namun harus membayar pajak khusus untuk orang non-muslim yang bernama jizya serta menerima sejumlah pembatasan untuk urusan-urusan ibadah di muka umum. Berada di dunia Islam membuat mereka terisolasi dari dunia Kristen. Mereka bahkan menjadi tidak tahu

${ }^{22}$ David R. Blanks and Michael Frassetto, "Introduction", Western Views of Islam in Medieval and Early Modern Europe: Perception of Other, ed. David R. Blanks \& Michael Frassetto (New York, NY.: St. Martin's Press, 1999), 1.

${ }^{23}$ Goddard, A History of Christian-Muslim Relations, 79.

${ }^{24}$ Ibid., 80.

${ }^{25}$ Ibid., 81 . 
bahasa Latin - bahasa resmi gereja di zaman itu. ${ }^{26}$ Di saat yang sama mereka juga diam di suatu wilayah di mana peradaban Islam begitu jauh meninggalkan peradaban Eropa. Perkembangan sains, filsafat, seni, literatur, arsitektur dan lain-lain jauh meninggalkan Eropa Kristen Barat. Hal ini menciptakan perasaan inferioritas kultural (cultural inferiority) di hadapan orang Islam sekaligus godaan yang amat kuat untuk meninggalkan kekristenan dan berasimilasi dengan agama dan budaya mayoritas. Inferioritas kultural inilah yang kemudian direspons dengan menciptakan citracitra negatif tentang Islam demi membuat diri merasa berharga di depan orang Islam. Orang Islam dan agama Islam, sebagai "yang lain", ditampilkan buruk dan jahat sementara diri sendiri adalah baik dan benar. ${ }^{27}$

Goddard mencatat secara khusus pemikiran dua orang Katolik di Cordoba, Eulogius, seorang imam, dan Paul Alvarus, seorang awam, tentang Islam. Memakai teks-teks apokaliptik di Kitab Daniel, Wahyu, dan sejumlah bagian seperti itu dalam kitabkitab Injil sinoptik, untuk memahami situasi mereka di dunia Islam dan apa Islam dan orang Islam itu. Misalnya, Daniel 7:19, 23-27 mereka pahami dirinya dan orang-orang Kristen sebagai orangorang kudus yang sedang dibuat menderita oleh suatu kekuatan yang sudah berhasil menundukkan kekaisaran-kekaisaran Yunani, Frankia, dan Goth. Kekuatan ini dikatakan sedang melawan Allah melalui kitab sucinya, sistem kalender dan sistem hukumnya. Namun dari teks itu mereka percaya bahwa ini hanya sebentar saja, hanya "satu masa dan dua masa dan setengah masa." Membaca Markus 13 dan Wahyu 13, Eulogius dan Alvarus menemukan kesamaan dengan situasi mereka di Cordoba saat itu. Mereka menyamakan Nabi Muhammad dengan Antikris karena tahun

\footnotetext{
${ }^{26}$ Goddard, A History of Christian-Muslim Relations, 79.

${ }^{27}$ Blanks \& Frassetto, Western Views of Islam in Medieval and Early Modern Europe, 3.
} 
kematiannya sama dengan tahun 666 - bilangan antikris - dalam kalender Spanyol. ${ }^{28}$

Dalam perkembangan selanjutnya, gambaran negatif tentang Islam dan orang-orang Islam terus berlanjut dan dibangun di atas situasi historis yang berbeda. Seiring dengan makin intensnya interaksi orang-orang di Eropa Barat dengan orang-orang dari berbagai tempat dan berbarengan pula dengan pemutusan relasi Gereja Barat dan Timur, maka mulai abad ke-11 di Eropa Barat mulai berkembang diskusi-diskusi tentang keeropaan (Europeanness) - apa itu Eropa, siapa orang Eropa, apa yang membedakannya dari yang bukan Eropa. Percakapan ini dibuat makin intens dan mengkerucut dalam gambar diri-gambar diri tertentu seiring dengan keterlibatan Eropa Barat dalam kampanye Perang Salib. Dalam proses mengkonsktruksi identitas diri itu, Islam dan orang-orang Islam, menjadi salah satu "yang lain" (the other), yang dipergunakan untuk mendefinisikan diri (the self). Islam dilihat sebagai "a threat of military nature as well as that of a cultural one in terms of representing 'the other', vis-à-vis Europe." Islam berfungsi sebagai alat untuk mendefinisikan keeropaan.

Pada abad ke-16 dan 17, Eropa Barat menghadapi tantangan baru dengan Islam, seiring dengan ekspansi kekuasaan yang dilakukan oleh Kekaisaran Ottoman Turki. Jatuhnya kota Konstantinopel (1453), ibukota Kekaisaran Romawi Timur, benteng Kristen di daerah Timur, menimbulkan kegelisahan tersendiri di kalangan rakyat dan penguasa Eropa. Serangan demi serangan ke Eropa, membawa kekuatan Ottoman mampu mendapatkan wilayah Balkan dan sejumlah wilayah di Eropa Tengah. Pada tahun 1529 dan 1683, mereka bahkan sempat masuk

\footnotetext{
${ }^{28}$ Goddard, A History of Christian-Muslim Relations, 81-84.
} 
menyerang Eropa Barat dan mengepung kota Wina, Austria. ${ }^{29}$ Dalam situasi permusuhan seperti ini, citra buruk dan negatif tentang orang Muslim dan Islam tercipta dan berkembang subur. ${ }^{30}$ Blanks dan Frasseto menulis demikian,

In both popular and learned literature Muslims were portrayed as cowardly, duplicitous, lustful, self-indulgent pagans who worshipped idols and a trinity of false gods. On the other hand, the creation of such a blatantly false stereotype enabled Western Christians to define themselves. Indeed, the Muslim became, in a sense, a photographic negative of the self-perception of an ideal Christian self-image, one that portrayed Europeans as brave, virtuous believers in the one true God and the one true faith. By debasing the image of their rivals, Western Christians were enhancing their own self-images and trying to build self-confidence in the face of a more powerful and more culturally sophisticated enemy. ${ }^{31}$

Baik dalam literatur populer maupun literatur terpelajar orang-orang Muslim digambarkan sebagai kafir pengecut, peniru, penuh nafsu dan suka mengikuti hawa nafsunya. Mereka menyembah berhala dan trinitas yang sesat. Dengan menciptakan stereotip-stereotip seperti itu, orang-orang Kristen Barat mendefinisikan dirinya sebagai yang sebaliknya. Dirinya adalah kaum pemberani, orang percaya yang baik, percaya kepada satu Allah yang benar dan pengikut iman yang benar. Dengan merendahkan citra rivalnya, orang-orang Kristen Barat meninggikan citra dirinya dan berusaha membangun kepercayaan dirinya di hadapan musuh yang lebih kuat dan yang lebih maju secara kultural.

\footnotetext{
${ }^{29}$ Jorgen S. Nielsen \& Jonas Otterbeck, Muslims in Western Europe, Fourth Edition (Edinburgh, UK.: Edinburgh University Press Ltd., 2016), 1-2.

${ }^{30}$ Blanks \& Frassetto, Western Views of Islam in Medieval and Early Modern Europe, 3.

${ }^{31}$ Ibid., 9-10.
} 


\section{Islam dalam Persepsi John Calvin}

Luther, Calvin, dan tokoh-tokoh Reformasi lainnya adalah anak-anak zamannya. Pikiran dan pandangan mereka dibangun di atas pengetahuan orang pada masanya tentang Islam. $^{32}$ Pengetahuan itu umumnya diperoleh dari literatur-literatur abad pertengahan tentang Islam dan dari kisah-kisah orang selama Perang Salib. Selain itu, kurangnya pengalaman berinteraksi langsung dengan orang Islam membuat tidak ada kemungkinkan untuk sedikit-dikitnya merevisi pemahaman mereka. ${ }^{33}$

Pemahaman literatur-literatur itu tentang Islam bersifat antagonistik. Islam dipandang sebagai "an archenemy of Christianity" $"$ musuh besar Kristianitas. Dengan citra semacam ini maka tidak heran bila dalam tulisan-tulisan abad pertengahan orang dapat menemukan segala macam cara untuk menyerang Islam dan orang-orang Islam. Mereka yang ada di barisan apologis (pembela iman Kristen) dan utusan Injil (misionaris) menyerang Al-Quran dengan maksud meruntuhkan ajaran-ajarannya. Para penafsir Kitab Suci (exegetes) dan teolog (theologians) menyerang Islam dengan memakai dalil-dalil yang dibangun di atas nubuatannubuatan para nabi di dalam Alkitab. Para pelancong dan peziarah ke Tanah Suci (the Holy Land) serta mereka yang dulunya adalah para tawaran tentara Turki Ottoman menyusun kisah-kisah perkenalan mereka dengan Islam dan orang-orang Islam dalam

${ }^{32}$ Fransisco, Martin Luther and Islam, 9, 97. Lihat juga Reformation and Islam, 16.

Fransisco menemukan bahwa ada empat literatur kunci yang dipakai Luther untuk memahami Islam. Itu adalah dua buku karangan Nicholas dari Cusa, yaitu Refutation of the Alcoran (Confutatio Alcorani) dan The Critique of the Alcoran (Cribratio Alkorani); sebuah traktat tulisan Georgius de Hungaria, yang berjudul Tractatus de moribus, condictionibus et nequicia Turcorum dan Al-Quran dalam terjemahan Latin, yang baru diperolehnya di kemudian hari di tahun 1542.

${ }^{33}$ Martin Luther sebenarnya pernah mendapat kesempatan untuk beraudiensi dengan raja Ottoman, Sultan Suleyman I, raja yang memimpin invasi dan pengepungan Kota Wina pada tahun 1529. Namun entah apa alasannya, ia memilih menolak memanfaatkan kesempatan itu. Fransisco dalam Concordia Theological Quaterly 71 (2007): 297.

${ }^{34}$ Fransisco, Concordia Theological Quaterly 71 (2007): 297. 
cara-cara yang membuat Islam dan orang muslim terlihat asing dan berbeda sekali dari orang-orang di Eropa Barat.

Tidak seperti Luther yang pernah membuat tulisan khusus tentang Islam, John Calvin tidak demikian. Meski demikian, pandangannya tentang Islam dan orang-orang Islam banyak bertebaran di dalam Institutio-nya, tafsiran-tafsiran Alkitab yang disusunnya dan bahkan dalam khotbah-khotbahnya. ${ }^{35}$ Bila Luther menyusun argumentasi-argumentasi teologisnya dari suatu situasi politik dan militer yang riil dengan kekuatan Islam, perhatian Calvin semata-mata fokus pada soal-soal teologis. ${ }^{36}$

Istilah-istilah yang dipergunakan Calvin untuk menyebut orang-orang muslim dan Islam adalah Turks, Saracens dan Mahomet. ${ }^{37}$ Dalam Institutio, istilah yang dipakai Calvin hanya Turks, dan muncul sebanyak 4 (empat) kali saja. Jumlahnya lebih banyak lagi dalam buku tafsirannya, tersebar di hampir tiga puluh halaman yang berbeda. Jumlah serupa juga ditemukan dalam khotbah-khotbahnya dari Kitab Ulangan. Rujukan lain tentang Islam yang tidak kalah banyaknya adalah Mahomet. Dalam bukubuku tafsiran Alkitabnya, istilah ini ditemukan di dua puluhan halaman yang berbeda. Jumlah serupa juga ditemukan dalam khotbah-khotbahnya dari Kitab Ulangan. Istilah yang agak jarang dipakai Calvin ialah Saracens. Istilah ini hanya muncul di lima halaman yang terpisah dalam buku tafsirannya, sementara dalam khotbahnya muncul sekali dengan nama Sarazins.

\footnotetext{
${ }^{35}$ Reformation and Islam, 19.

${ }^{36}$ Ibid.

${ }^{37}$ Untuk Institutio, tafsiran dan khotbah Calvin yang dipergunakan di sini ialah sbb.: John T.McNeill, ed., Calvin Institutes of the Christian Religion Vol. I-II, Ford Lewis Battles, transl. (Louisville, KY.: Westminster John Knox Press, 2006); Calvin's Commentaries Complete, Calvin Translation Society Edition dalam http://www.ccel.org/ccel/calvin/commentaries.html, sementara untuk khotbah diambil dari khotbah Calvin dari Kitab Ulangan dalam https://www.monergism.com/sermonsdeuteronomy-ebook.
} 
Dalam Institutio, rujukan-rujukan tentang orang-orang Turks adalah sebagai berikut,

"So today the Turks, although they proclaim at the top of their lungs that the Creator of heaven and earth is God, still, while repudiating Christ, substitute an idol in place of the true God." [II.6.4].

"Therefore, those who prate that we are justified by faith because, being reborn, we are righteous by living spiritually have never tasted the sweetness of grace, so as to consider that God will be favorable to them. Hence, it also follows that they no more know the right way to pray than do the Turks and other profane nations." [III.13.5].

"Accordingly, either Christ's promise is vain, or they are not, at least in this regard, churches. Finally, instead of the ministry of the Word, they have schools of ungodliness and a sink of all kinds of errors. Consequently, by this reckoning either they are not churches or no mark will remain to distinguish the lawful congregations of believers from the assemblies of Turks." [IV.2.11]

"But those infants who derive their origin from Christians, as they have been born directly into the inheritance of the covenant, and are expected by God, are thus to be received into baptism. To this ought to be referred the Evangelist's statement that those who confessed their sins were baptized by John (Matt. 3:6). We think that this example ought to be observed today. For if a Turk should offer himself for baptism, we could not easily baptize him unless he gave a confession satisfactory to the church." [IV.16.24]

Bagian II.6.4. berada dalam rangkaian pembicaraan tentang pengetahuan mengenai Allah Sang Penebus, yang nyata di dalam Tuhan Yesus Kristus. Iman yang benar kepada Allah tidak bisa terjadi tanpa iman kepada Kristus, sebab "God is comprehended in Christ alone." Tanpa percaya kepada Kristus pengetahuan yang orang punya tentang Allah hanyalah "a fleeting knowledge of God." Inilah yang membedakan iman Kristen dari yang lain. Meski orang- 
orang muslim diakui oleh Calvin percaya bahwa Allah adalah "the Creator of heaven and earth" namun karena mereka menolak Kristus maka yang mereka percayai tentang Allah hanyalah "an idol' - suatu berhala saja.

Hal senada Calvin amat tegaskan dalam khotbah ke-45 dari Ulangan pasal 6, pada tanggal 19 Juli 1555. Di kesempatan itu ia sampaikan demikian,

"The Heathen wandered at rovers, so as every man said I worship God. And yet in the meanwhile, what was it they did? Nothing but dreams and fantasies: for when men take upon them to worship God without knowing him: no doubt but they worship idols. The Turks at this day do say they worship the God that made heaven and earth: but yet is it but an idol which they worship. And how so? They name him the maker of heaven and earth, and they have none images. That is true: but yet for all that, they have but an idol instead of, God, because they admit not our Lord Jesus Christ, who is the lively image of God his father."

Sekalipun orang-orang Muslim mengaku menyembah Allah yang menciptakan langit dan bumi dan mereka sama sekali tidak membuat patung-patung namun mereka, menurut Calvin, tetap menyembah berhala. Alasannya ialah karena mereka tidak mengakui Tuhan Yesus Kristus, yang adalah gambar yang hidup dari Allah Bapa-Nya. ${ }^{38}$ Di tempat di mana Allah Anak seharusnya berada, orang-orang muslim, menurut Calvin, karena tidak percaya bahwa Allah dapat memanifestasikan dirinya di dalam daging maka menggantinya dengan "Mahomet."39

Apakah orang Muslim tidak tahu bahwa mereka menyembah berhala? Di sini, dalam khotbahnya, Calvin berpendapat bahwa hal

\footnotetext{
${ }^{38}$ Muslim yang menyembah berhala dapat pula dilihat dalam khotbah ketiga Ulangan 9, Kamis, 29 Agustus 1555.

${ }^{39}$ Khotbah ketiga dari Ulangan 13, 16 Oktober 1555.
} 
itu dapat terjadi "through deceitfulness of their Mahomet who has bewitched them." 40 Tak ada sedikitpun respek kepada Muhammad, seperti tercermin dalam khotbahnya dari Kitab Ayub, seperti yang dikutip oleh Professor Nigel Lee,

"Mahomet has reported himself to be the party that should bring the full revelation - over and besides the Gospel. And by means thereof, they [the Islamic Turks] have utterly become brute beasts... At this day, we see that those poor beasts busy their heads about as doltish and unsensible things as any can be. But it is the just vengeance of God, Who has given them over to a wil-ful stubborn mind!"

Also the equally-unitarian Anabaptist Servetus "said that the Holy Ghost had not reigned as yet - but that He was to come.... He would have made himself a Mahomet, to have the Holy Ghost at his command.... But let us content us with the Holy Scripture seeing that God has enclosed us within the bounds thereof!" John $14: 16$ \& $14: 26$ and $15: 26$ and 16:7-15.,"41

Di sini Nabi Muhammad dikatakan mengakui dirinya menerima wahyu yang lebih tinggi dari Injil. Namun apa yang dihasilkan oleh wahyu itu ialah orang-orang, yang menurut Calvin, tidak sama tingginya dengan klaim itu.

Dalam keseluruhan tulisan Calvin, orang-orang Muslim hampir selalu didudukkan bersama dengan orang Katolik (the Papist) dan Yahudi. Yang lain ialah dengan orang Heathen dan Paynim. Dua yang terakhir ini menunjuk kepada penyembah berhala. $^{42}$

\footnotetext{
${ }^{40}$ Khotbah keempat dari Ulangan 11, 25 September 1555. Terjemahan: 'karena kecurangan Mahomet yang telah membuat mereka terpesona.'

${ }^{41}$ Professor Francis Nigel Lee, Calvin On Islam (El Paso, TX.: Lamp Trimmers, 2000), tanpa halaman. Nigel Lee adalah dosen sejarah gereja di Queensland Presbyterian Theological College, Australia. Cetak tebal adalah dari Nigel Lee sendiri.

${ }^{42}$ Kata Paynim berasal dari kata Anglo-Norman paienime, peinime, yang berasal dari kata Prancis kuno paienime. Kata ini kata Latin paganismus dan pagan. Lihat http://www.dictionary.com/browse/paynim (diakses pada 17 Agustus 2017).
} 
Meski sangat negatif sekali namun ada kalanya orang-orang muslim (dan juga orang Yahudi) dalam pandangan Calvin keadaannya masih sedikit lebih baik dari orang-orang Katolik. Dalam khotbah pertama dari Ulangan 11 pada 11 Oktober 1555, Calvin mengatakan bahwa pada suatu khotbah ia mengatakan tentang ketiganya demikian, "the Turks and Jews are not more fiery and venomous at this day against God, to deface the whole doctrine of salvation than are the Papists. ${ }^{, 43}$

\section{Kalau Demikian, Dapatkah Orang Kristen Bersekutu dengan Orang-Orang Muslim?}

Konteks percakapan Calvin dalam Institution IV.2.10 ialah tentang gereja. Dalam bagian sebelumnya (IV.2.9) argumennya jelas bahwa gereja Katolik Roma pada saat itu telah rusak. Ia melukiskan keadaannya seperti Israel di zaman raja Yerobem (IV.2.7). Apa yang diperbuat dalam gereja ini "had not been instituted by God" (IV.2.9) - tidak diperintahkan oleh Tuhan dan "contaminated with idolatry, superstition and ungodly doctrine" (IV.2.10) - penyembahan berhala, tahayul dan doktrin yang sesat. Dengan cara ini maka mereka membuat orang yang mau membedakan jemaat-jemaat orang-orang percaya dari perkumpulan-perkumpulan orang Muslim.

Dalam padangan Calvin, orang Kristen tidak bisa bersekutu dengan orang Muslim karena "they were not the badge of Baptism, and despise the God whom we worship. ${ }^{, 44}$ Meski mengakui orang muslim melakukan pembasuhan berkali-kali - yang dimaksud

\footnotetext{
${ }^{43}$ Terjemahan: orang-orang Turk dan Yahudi pada hari ini tidak lebih berapi-api dan beracun terhadap Allah, merusakkan seluruh doktrin keselamatan dari pada yang diperbuat oleh orang-orang Katolik Roma.

${ }^{44}$ Khotbah kedua dari Ulangan 14, 23 Oktober 1555. Terjemahan: 'mereka bukan lencana baptisan dan memandang hina Allah yang kita sembah.'
} 
Calvin adalah wudhu - namun itu sama sekali tidak sama artinya dengan baptisan. Itu "no better than the holy water of the Papists",45 - tak lebih dari air suci orang Katolik saja! Kalaupun kemudian ada orang Muslim yang mau dibaptis, Calvin berpendapat bahwa hal itu tidak boleh dengan mudah dilakukan, kecuali ia telah memperlihatkan pengakuan yang memuaskan kepada gereja (Institutio IV.16.24). Perlakuan pada seorang bayi dari orang tua Kristen lebih baik dari orang Muslim karena ia dilahirkan ke dalam warisan perjanjian. Ia dapat langsung dibaptiskan.

Masih banyak lagi yang bisa disajikan dari data-data yang tersedia. Semua itu dengan sangat lengkap dapat diperoleh dari tulisan Francis Nigel Lee dan Emidio Campi. Apa yang mau disajikan di sini ialah sekedar memberi gambaran kecil dari apa yang dipikirkan Calvin tentang Islam dan orang-orang Islam.

\section{SIMPULAN}

Dari apa yang disajikan di atas kiranya menjadi jelas bahwa Islam, yang direpresentasikan secara dominan dalam diri orangorang Turks Ottoman, bukanlah penyebab langsung dari munculnya Reformasi Gereja. Meski demikian, Kekaisaran Islam Ottoman yang menginvasi Eropa mulai abad ke-15 telah memberi kontribusi tidak langsung kepada terjadinya Reformasi, pada kelangsungannya dan penyebarannya. Invasi itu membantu menciptakan sebuah situasi yang tidak dapat direspons dengan memadai oleh kekuatan politik dan militer Katolik. Aksi Luther dan tokoh-tokoh Reformasi lainnya di sejumlah kota di Jerman dan Swiss kelihatannya diharapkan oleh penguasa dapat diselesaikan oleh Gereja Katolik supaya mereka dapat berkonsentrasi menghadapi lawan yang sudah semakin dekat. Namun tanpa

\footnotetext{
${ }^{45}$ Ibid.
} 
dukungan kekuasaan politik penguasa Katolik, perlawanan itu tidak mampu mencegah dan menghalangi dampak Reformasi yang luas.

Persepsi negatif tentang Islam dan orang-orang Islam yang dijumpai pada orang-orang Kristen Eropa Barat, pada tokoh-tokoh Reformasi dan orang-orang Kristen Eropa Barat selanjutnya, seperti sudah ditunjukkan di atas, terbentuk karena konflik-konflik yang terjadi sebelumnya di antara orang Kristen Eropa Barat dan Islam. Dimulai dari masa penaklukkan Spanyol dan Portugis dan makin berkembang lagi di masa Perang Salib. Persepsi-persepsi itu tercipta dan berkembang dalam suasana yang diwarnai kegelisahan, kecemasan, dan ketakutan akan musuh yang hebat.

Di pihak lain, kemajuan peradaban Islam yang jauh meninggalkan peradaban Eropa Barat telah menimbulkan perasaan inferioritas terhadap Islam di kalangan orang-orang Kristen Eropa Barat. Merendahkan orang lain dalam rangka mengangkat diri sendiri adalah mekanisme mental yang ditempuh untuk membangun kepercayaan diri. Bersamaan dengan itu, timbulnya usaha-usaha untuk menentukan identitas keeropaan bersamaan dengan munculnya di era Perang Salib, membuat orang-orang Islam diposisikan sebagai salah satu "yang lain" (the other) terhadap mana diri sendiri diidentifikasi. Islam menjadi kebalikan dari keeropaan. Kalau keeropaan itu baik maka Islam adalah buruk. Sayang sekali pandangan-pandangan ini dikembangkan terlepas dari kontak personal yang intens dengan orang-orang Islam. Tak pernah pula ada dialog langsung dengan pemikir-pemikir Islam yang sezaman atau mendapat respons langsung dari pihak Islam.

Catatan yang perlu diperhatikan oleh orang-orang Kristen di Indonesia ialah pentingnya memeriksa persepsi-persepsi kita sendiri terhadap Islam dan orang-orang Islam di sini. Pengalamanpengalaman buruk yang dialami orang terhadap orang lain adalah pemicu yang paling mudah untuk mengeluarkan sikap dan 
prasangka buruk terhadap yang lain. Seperti dialami orang-orang Kristen di Eropa Barat abad pertengahan, begitu mudah sekali pandangan buruk ini diteruskan dari generasi demi generasi secara tidak kritis. Di sini dialog intens dengan yang lain menjadi penting. Namun, seperti diingatkan Campi, dialog tidak boleh hanya sekedar bercakap-cakap - small talk, istilah Campi - tetapi harus merupakan sebuah percakapan terus-terang dan mendalam di mana dimensi-dimensi mendalam iman masing-masing dipercakapkan. ${ }^{46}$ Di sini menjadi penting artinya menyediakan ruang-ruang yang aman, nyaman dan bebas tekanan bagi kedua belah pihak untuk dapat berdiskusi.

\section{DAFTAR RUJUKAN}

PUSTAKA:

Aritonang, Jan S. Sejarah Perjumpaan Kristen dan Islam di Indonesia. Jakarta: BPK Gunung Mulia, 2006.

Blanks, David R. \& Michael Frassetto, "Introduction", Western Views of Islam in Medieval and Early Modern Europe: Perception of Other. David R. Blanks \& Michael Frassetto, eds. New York, NY.: St. Martin’s Press, 1999.

Calvin, John. Institutes of the Christian Religion Vol. I-II. Ford Lewis Battles, transl. Louisville, KY.: Westminster John Knox Press, 2006.

Campi, Emidio. "Early Reformed Attitudes towards Islam", Theological Review 31, 2010: 131. 150.

${ }^{46}$ Campi, "Early Reformed Attitudes towards Islam”, Theological Review 31, 2010: 
Fransisco, Adam S. "Luther, Lutheranism and the Challenge of Islam," Concordia Theological Quaterly 71 (2007): 283-300. . Martin Luther and Islam: A Study in SixteenthCentury Polemics and Apologetics. Leiden: Koninklijke Brill NV, 2007.

Frederiks, Martha. "Introduction: Christians, Muslims and Empires in the 16th Century," Christian-Muslim Relation: A Bibliographical History Volume 6. Western Europe (15001600), David Thomas \& John Chesworth, eds. Leiden: Koninklijke Brill NV, 2014.

Goddard, Hugh. A History of Christian-Muslim Relations. Edinburgh, UK.: Edinburgh University Press, 2000.

Goffman, Daniel. The Ottoman Empire and Early Modern Europe. Cambridge, UK.: Cambridge University Press, 2004.

Lee, Francis Nigel. Calvin On Islam. El Paso, TX.: Lamp Trimmers, 2000.

Nielsen, Jorgen S. \& Jonas Otterbeck. Muslims in Western Europe. 4th Edition. Edinburgh, UK.: Edinburgh University Press Ltd., 2016.

Reformation and Islam: A Stimulus Paper from the Conference for Islam Issues of the Evangelical Church in Germany (EKD). Hannover: Evangelische Kirche in Deutschland [EKD], 2016). 
90 Reformasi Gereja, John Calvin dan Islam

Soykut, Mustafa. The Image of the Turk in Italy: A History of the "Other" in Early Modern Europe: 1453 -1683. Berlin: Klaus Schwarz Verlag, 2001.

\section{INTERNET}

. Calvin's Commentaries Complete. Calvin Translation Society Edition dalam http://www.ccel.org/ccel/calvin/commentaries.html.

. Sermons on Deuteronomy dalam

https://www.monergism.com/sermons-deuteronomy-ebook.

Szczepanski, Kallie. "Who were the Saracens" dalam https://www.thoughtco.com/who-were-the-saracens-195413 (diakses pada 27 Juli 2017). 